\author{
AGNIESZKA GÓRNICZ-MULCAHY \\ ORCID: 0000-0003-1767-4709 \\ Uniwersytet Wrocławski \\ Instytut Prawa Cywilnego \\ Zakład Prawa Pracy
}

\title{
PRACOWNICZE OCENY OKRESOWE - WYBRANE ELEMENTY
}

\begin{abstract}
Abstrakt: Oceny okresowe stanowią obecnie stały element stosunku pracy. Mechanizm ocen istniejący w służbie publicznej przewiduje również ujemne skutki związane z procesem jego stosowania. Zadaniem artykułu jest zwrócenie uwagi, że głównym celem ocen okresowych jest jednak ich wymiar pozytywny, nakierowany na proces rozwoju zawodowego pracownika, podnoszenia jego kwalifikacji i rozwijania kompetencji. Na gruncie pragmatyk pracowniczych zadanie to jest o tyle utrudnione, że postępowanie pracodawcy nie jest dowolne, lecz powinno koncentrować się na ocenie określonych normatywnie kryteriów za pomocą obiektywnego miernika (art. 94 pkt 9 k.p.).
\end{abstract}

Słowa kluczowe: stosunek pracy, ocena okresowa, sprawiedliwe i obiektywne kryteria

\section{UWAGI WSTĘPNE}

Zarówno podporządkowanie pracownika pracodawcy w procesie pracy, jak i uprawnienia kierownicze pracodawcy stanowią właściwość stosunku pracy i przesądzają o jego istocie. Uprawnienia kierownicze pracodawcy i wchodząca w ich zakres kompetencja pracodawcy, zarówno publicznego, jak i prywatnego, do oceniania pracowników jest wpisana w istotę pracy, która ze swej natury wynikającej ze stosunku pracy ma właśnie charakter pracy podporządkowanej. Innymi słowy, dokonywanie oceny stanowi działanie pracodawcy w stosunku do pracownika $\mathrm{w}$ ramach przyznanych mu uprawnień. Jednocześnie służy zorganizowaniu i uporządkowaniu procesu pracy, a także powinno przyczyniać się do budowania wzorców dobrych zachowań i właściwych postaw pracowników. W doktrynie uważa się, że obowiązek poddania się ocenie okresowej (kwalifikacyjnej) jest elementem składowym obowiązku wykonywania pracy, a oceny służą weryfikacji przydatności pracowników do pracy ${ }^{1}$. Ustawodawca nie wskazuje jednak wprost

1 Zob. H. Szewczyk, Stosunki pracy w stużbie cywilnej, Warszawa 2010, s. 220. 
ani celu, ani funkcji (istoty) przeprowadzanych ocen, co powoduje, że w większości przypadków są one instrumentem służącym pracodawcy do weryfikowania (pod względem jakości i ilości) wykonywanych przez pracownika obowiązków. Natomiast nie wolno zapominać, w procesie kształtowania ocen, o konieczności uwzględnienia istniejących osiągnięć nauki w zakresie zarządzania zasobami ludzkimi. Istotne jest również pytanie o bezpośredni cel ocen okresowych oraz czemu i komu mają służyć wyniki uzyskane wskutek przeprowadzonej procedury. Czy na ich podstawie pracodawca powinien ustalać drogę dalszego rozwoju pracownika (indywidualny program rozwoju zawodowego pracownika), uwzględnić go w systemie wzrostu wynagrodzeń lub przy gratyfikacjach finansowych, otworzyć mu procedury awansowe, ustanawiając tym samym narzędzie kwalifikowania pracowników do ewentualnego awansu, czy — w końcu — rozwiązać z nim stosunek pracy.

W polskim systemie prawa pracy brakuje przepisów, które regulowałyby kompleksowo procedurę okresowych ocen pracowników. Nie ma również przepisów o charakterze powszechnie obowiązującym, które określałyby częstotliwość takich ocen oraz sposób ich prowadzenia. Mechanizm ocen okresowych jako stały element stosunku pracy przewidują jedynie pragmatyki (akty normujące stosunki pracy w sferze prawa publicznego). Stanowią one środek, który realizuje podkreślany wcześniej postulat kierownictwa pracodawcy znajdujący swą podstawę prawną właśnie $\mathrm{w}$ treści tych aktów ${ }^{2}$. W zależności od regulacji mechanizmy dokonywania ocen okresowych różnią się od siebie stopniem sformalizowania, katalogiem kryteriów i odmiennym okresem ocennym, a nawet wskazanym celem ${ }^{3}$. Jest to związane również z szerokim pojęciem służby publicznej, do której zaliczane są osoby o różnym statusie zatrudnienia. Zadania należące do tej kategorii pracowników wykonują osoby wyłonione w drodze wyboru, powołania, nominacji lub umowy o pracę. Niewątpliwie sposób wykonywania przez te podmioty obowiązków pracowniczych (w tym też uregulowania dotyczące jego wersyfikacji), które z założenia nacechowane są pierwiastkiem publicznym i które nakierowane są na realizację interesu publicznego, wpływa bezpośrednio na jakość działania administracji publicznej ${ }^{4}$. W tym wymiarze oceny mają zatem wprost służyć polepszaniu jakości usług świadczonych ze strony administracji. Natomiast w przypadku nauczycieli akademickich ocena okresowa stanowi instrument pozwalający

2 Przykładowo: art. 37, 38 i art. 71 ustawy z dnia 21 listopada 2008 roku o służbie cywilnej, tekst jedn. Dz.U. z 2018 r. poz. 1559; art. 27 ustawy z dnia 21 listopada 2008 roku o pracownikach samorządowych, tekst jedn. Dz.U. z 2019 r. poz. 1282; art. 128 ustawy z dnia 20 lipca 2018 roku Prawo o szkolnictwie wyższym i nauce, tekst jedn. Dz.U. z 2018 r. poz. 1915; art. 20 ustawy z dnia 16 września 1982 roku o pracownikach urzędów państwowych, tekst jedn. Dz.U. z 2018 r. poz. 1915.

$3 \mathrm{~W}$ istniejącym kształcie prawnym oceny okresowe pracowników samorządowych sprowadzają się jedynie do obowiązku stron stosunku pracy, który nie został powiązany z systemem awansowania pracownika.

${ }^{4}$ Zob. A. Dubowik, Ł. Pisarczyk, Prawo urzędnicze, Warszawa 2011, s. 139 n. 
pracodawcy na monitorowanie ich postępów w celu zapewnienia najwyższego poziomu nie tylko naukowego, ale również kształcenia 5 .

W doktrynie prezentowane są poglądy świadczące o tym, że oceny okresowe, jakkolwiek są elementem kontroli sprawowanej w ramach kierownictwa pracodawcy $^{6}$ (art. $22 \S 1$ k.p.), nie mogą zastępować kar porządkowych ${ }^{7}$. Natomiast na gruncie pragmatyk wspólnym mianownikiem mechanizmu ocen funkcjonującego aktualnie w służbie publicznej są ujemne skutki związane z otrzymaniem negatywnego wyniku w procesie ich dokonywania, wprost wyrażone w ustawie. Pracodawca jest uprawniony do rozwiązania stosunku pracy w razie uzyskania przez pracownika jednej negatywnej oceny okresowej (na przykład art. 123 ust. 1 pkt 1 ustawy z dnia 20 lipca 2018 roku - Prawo o szkolnictwie wyższym i nauce; art. 13 ustawy z dnia 16 września 1982 roku o pracownikach urzędów państwowych) lub zobligowany do jego rozwiązania (na przykład art. 71 ust. 1 pkt 1 ustawy z dnia 21 listopada 2008 roku o służbie cywilnej). W konsekwencji wynik (negatywny) dokonanej oceny okresowej rzutuje na całą karierę pracownika bez względu na poprzednio uzyskane oceny pozytywne. Wydaje się, że powyższa zależność powinna być standardem także przy pozytywnym wyniku oceny, który przecież w naturalny sposób ma stanowić klucz otwierający drogę do powierzenia pracownikowi wyższego stanowiska (otwarcia procedury awansowej lub wprost samego awansu zawodowego). Oznacza to, że między systemem dokonywania ocen okresowych a systemem awansowania pracowników powinien występować ścisły związek. Takim przykładem jest mechanizm zawarty w ustawie o służbie cywilnej, który przewiduje, że na podstawie wyników oceny okresowej ustala się indywidualne programy dalszego rozwoju zawodowego członka korpusu służby cywilnej. Natomiast takiego przełożenia nie znajdziemy na gruncie ustawy o pracownikach samorządowych, gdzie nie ma powiązania wyniku uzyskanego w procesie oceniania z systemem awansowania pracownika. Stąd wniosek, że deklarowany cel ocen w postaci podnoszenia standardów pracy w jednostkach samorządowych nie jest realizowany, a oceny tracą swój najważniejszy sens.

\section{POJĘCIE OCENY OKRESOWEJ}

Ocena okresowa nie ma definicji legalnej. Co więcej, w zależności od płaszczyzny stosowania może być też różnie pojmowana. Bez względu jednak, czy będzie definiowana przez pryzmat założeń teorii i organizacji zarządzania zasobami

5 Zob. A. Bocheńska, [w:] Akademickie prawo zatrudnienia. Komentarz, red. K.W. Baran, LEX 2020.

6 A. Sobczyk, Państwo zakładów pracy, Warszawa 2017, s. 272.

7 K. Kulig, Teoria pracowniczej odpowiedzialności porządkowej, Warszawa 2017, Legalis, r. VI 33 in fine. Szerzej P. Krzyżaniak, Interes publiczny w rozgraniczeniu funkcji oceny pracowniczej $i$ kary porzadkowej w zaktadzie pracy, MPP 2019, nr 2, Legalis. 
ludzkimi, czy przepisów prawa pracy ${ }^{8}$ stanowi ona instrument, którego bezpośrednim celem jest weryfikowanie jakości zatrudnionych kadr (w zakresie posiadanych kompetencji) oraz monitorowanie rozwoju pracownika, w tym podnoszenia przez niego kwalifikacji zawodowych. W doktrynie wskazuje się również, że obowiązek poddania się ocenie okresowej ma służyć zapewnieniu odpowiedniego poziomu merytorycznego kadry urzędniczej ${ }^{9}$. Niewątpliwie posiadane przez pracownika, a oceniane w toku tej procedury kompetencje określają postawy, zachowania oraz umiejętności szczególnie cenione przez pracodawcę.

Wypaczeniem rozumienia pojęcia oceny okresowej będzie natomiast twierdzenie, że jest ona wyłącznie narzędziem kontroli. Wiąże się z tym wątpliwość, czy ustawodawca, wprowadzając sformalizowany system dokonywania ocen okresowych w pragmatykach pracowniczych, pod względem zakresu podmiotowego i kryteriów oceny, przewidział wymierny sposób wykorzystania jej wyników. Istotą oceny okresowej jest przede wszystkim udzielanie pracownikom informacji zwrotnej na temat wykonywanej przez nich pracy (przede wszystkim pod względem jakości). Ocena zatem powinna stanowić kluczowy element systemu motywacji i rozwoju zawodowego pracownika, co nie wyklucza jednocześnie możliwości klasyfikowania jej jako elementu kontroli sprawowanej w ramach kierownictwa pracodawcy.

W teorii zarządzania zasobami ludzkimi przyjmuje się, że ocena okresowa jest sądem wartościującym, wykorzystywanym w procesie zarządzania, który powstaje w wyniku porównania cech, kwalifikacji, zachowań czy też efektów pracy konkretnego pracownika w odniesieniu do innych pracowników lub też do ustalonego wzorca (standardu $)^{10}$. Ma ona charakter sformalizowany, dokonywana jest w sposób systematyczny, z zastosowaniem zasad i procedur, które w służbie publicznej mają normatywnie ukształtowany charakter. Modelowa ocena okresowa ma charakter kompleksowy, obejmuje całokształt efektów pracy ocenianego pracownika, zawiera również elementy oceny jego umiejętności oraz postawy wobec pracy ${ }^{11}$. Dlatego w procesie oceny zachowań i postaw pracownika pod uwage powinny być brane opinie współpracowników, podwładnych, przełożonego (ewentualnie klientów), a następnie oceny te powinny zostać zestawione z samooceną. Wówczas ocena okresowa jako taka będzie kompatybilna z pracowniczym obowiązkiem sumiennego i starannego wykonywania pracy (art. 100 $\S 1$ k.p.). Zarówno sumienność, jak i staranność wykonywania pracy uznaje się za miary należytego wykonywania zobowiązania pracowniczego. Szczególne znaczenie ma pojęcie staranności, które wskazuje na miarę obiektywną. Funkcjonują-

${ }^{8}$ Które - niewątpliwie - powinny uwzględniać dorobek nauki o zarządzaniu zasobami ludzkimi.

9 Zob. A. Dubowik, Ł. Pisarczyk, Prawo urzędnicze, Warszawa 2011, s. 158.

10 Zob. A. Ludwiczyński, [w:] Zarządzanie zasobami ludzkimi. Podręcznik, red. A. Ludwiczyński, H. Król, Warszawa 2006, s. 266.

11 Zob. ibidem, s. 267. 
ce zróżnicowane wzorce staranności, odnoszone do pracowników wykonujących określony zawód i zajmujących określone stanowiska, będą wyznaczały między innymi kryteria oceny pracowniczej.

Można zatem przyjąć, że ocena okresowa to wielopłaszczyznowa ocena jakości pracy pracownika dokonywana przez pracodawcę $\mathrm{w}$ ramach przysługujących mu uprawnień kierowniczych. Nie wolno jednak pominąć, że jakość świadczonej pracy będzie uzależniona również od warunków, w jakich jest ona wykonywana. Dlatego też wymogiem dokonania prawidłowej oceny pracowniczej powinna być troska podmiotu zatrudniającego o odpowiednie warunki pracy. Wyniki oceny są zaś podstawą planowania dalszego rozwoju pracowników, typowania do szkoleń, planowania wynagrodzeń, sukcesji oraz innych decyzji kadrowych.

\section{FUNKCJA I CEL OCENY OKRESOWEJ}

Ocena okresowa pracownika, co już było podkreślane, to działanie pracodawcy zmierzające do wartościowania pracowników przez dokonywanie oceny zarówno ich samych, jak i wyników ich pracy, co w szerszej perspektywie, zarówno w praktyce jak i w teorii, stanowi element zarządzania zasobami ludzkimi. Dokonywanie ocen okresowych pracowników nie jest więc celem samym w sobie, ale ma służyć i wspierać efektywność pracodawcy, a w perspektywie służby publicznej ma także wpływać pozytywnie na jakość działania całej administracji publicznej. Ocena okresowa ma również służyć pracownikowi, weryfikacji poziomu jego rozwoju, lepszemu zrozumieniu wymagań dotyczących wykonywanych przez niego obowiązków, szczególnie jeśli te są nakierowane na realizację interesu publicznego, identyfikowaniu i analizowaniu ewentualnych problemów w ich wykonywaniu. Dlatego też istotnym elementem oceny okresowej jest udzielenie pracownikowi informacji zwrotnej w taki sposób, żeby była dla niego nie tylko motywująca do dalszego wykonywania obowiązków w sposób prawidłowy, ale także konstruktywna i rozwojowa. Uzyskanie tego rezultatu może nastąpić również przez odniesienie do efektów osiąganych przez osoby na stanowiskach równorzędnych, a także stwierdzenie mniejszej skuteczności w porównaniu z okresem poprzednim ${ }^{12}$. Nie wystarczy założenie, że postulat przekazania informacji zwrotnej spełniają uwagi wypływające $\mathrm{z}$ opinii zawartych w formularzu oceny, w szczególności, jeśli ta przewiduje skalę dwustopniową (ocena pozytywna, ocena negatywna). Poprawnie przeprowadzona ocena sama w sobie powinna stanowić źródło motywacji do lepszego wykonywania powierzonych pracownikom zadań, a tym samym wpływać na efektywność pracy. Takie oddziaływanie oceny okresowej na pracownika, pozwalające mu na wyeliminowanie niepożądanych, a ujawnionych

12 Zob. L. Mitrus, Wypowiedzenie umowy o prace z przyczyn dotyczacych pracownika, Warszawa 2018, Legalis. 
w ocenie zachowań związanych z wykonywaniem obowiązków pracowniczych, określane jest jako funkcja korekcyjna oceny ${ }^{13}$. Przykładowo w służbie cywilnej przyjmuje się, że obowiązek omówienia oczekiwań co do sposobu spełniania kryteriów oceny, a także celów do osiągnięcia w okresie, w którym oceniany podlega ocenie, oraz sposobu realizacji tych celów, w tym kierunków dalszego rozwoju zawodowego i potrzeby ocenianego w zakresie podnoszenia kwalifikacji i doskonalenia umiejętności, z natury rzeczy nie może mieć charakteru szczegółowego wyliczenia pożądanych zachowań pracownika w ściśle sprecyzowanych sytuacjach, które przecież mają zaistnieć w przyszłości ${ }^{14}$.

Natomiast żeby ocena okresowa mogła osiągnąć swój cel, pracodawca, będąc z kolei dysponentem celu, dla którego pracownik został zatrudniony na danym stanowisku, przed rozpoczęciem okresu ocennego powinien wyraźnie określić zadania (cele) stawiane pracownikowi, szczególnie co do jakości pracy (jej poziomu merytorycznego), dyscypliny pracy, właściwego wykonywania obowiązków czy też odpowiedniego przygotowania zawodowego. Innymi słowy, cechą charakterystyczną umowy o pracę jest to, że stanowi ona umowę starannego działania (art. $100 \S 1$ k.p.). Pracownik zatem zobowiązuje się jedynie do starannego działania, które polega na dołożeniu należytej staranności w zmierzaniu do określonego celu, a samo osiągnięcie tego celu jest już poza treścią stosunku zobowiązaniowego łączącego pracownika z pracodawcą. Aby pracownik mógł zmierzać do owego celu, musi go jednak znać, co nie będzie możliwe, jeśli nie zostanie o nim poinformowany przez pracodawcę określającego jego warunki zatrudnienia. Pracownik, któremu powierza się określone stanowisko i stawia wymagania, powinien być oceniany właśnie przez pryzmat wyznaczonych mu obowiązków i wymagań. Szczególnego waloru powyższa zależność nabiera na gruncie pragmatyk, gdzie wiele obowiązków pracowniczych ma charakter publicznoprawny. Stąd tak duże znaczenie wniosków i zaleceń odnoszących się do dalszego rozwoju zawodowego pracownika. Ich rolą jest bowiem ukierunkowanie pracownika w ten sposób, aby „wyniki pracy”, które odnoszą się do jego efektywności oraz osiąganych przez niego rezultatów, zostały odnotowane przez pracodawcę na poziomie oczekiwanym (wskazanym), również zgodnie z obowiązującymi w tym zakresie przyjętymi standardami ustawowymi.

W doktrynie podkreśla się, że ocena okresowa ma na celu nie tylko rozliczanie pracowników z wykonywanych obowiązków, lecz także wyznaczanie kierun-

13 Z. Góral, Funkcja ocen okresowych nauczycieli akademickich [w:] Prawny model zatrudnienia nauczyciela akademickiego. Wybrane zagadnienia, red. A. Bocheńska, A. Musiała, Poznań 2016, s. 112.

14 Zob. § 10 rozporządzenia z dnia 4 kwietnia 2016 roku w sprawie warunków i sposobu przeprowadzania ocen okresowych urzędników służby cywilnej i pracowników służby cywilnej, Dz.U. z 2016 r. poz. 470. Wyrok Sądu Najwyższego z dnia 25 sierpnia 2015 roku, II PK 223/14, LEX nr 2026882. 
ków ich rozwoju, motywowanie i mobilizowanie ${ }^{15}$, w tym też budowanie własnej wartości jako pracownika. W tej płaszczyźnie ocena okresowa postrzegana jest jako narzędzie do mierzenia poziomu kompetencji pracownika, w szczególności jeśli chodzi o stanowiska związane z odpowiedzialnością za pracę zespołu czy podejmowane decyzje. Jej celem powinna być więc pomoc pracownikom w rozwijaniu kompetencji właśnie oraz osiąganiu coraz lepszych wyników w podejmowanych przez nich działaniach. W konsekwencji takie oddziaływanie oceny ma się przełożyć na stale podnoszoną jakość pracy, w efekcie - lepsze jakościowo wykonywanie obowiązków pracowniczych. Natomiast w kontekście dominującego w pragmatykach pracowniczych wzorca, jakim jest rozwiązanie stosunku pracy po otrzymaniu dwóch ocen (opinii) negatywnych, niezwykle istotne staje się działanie pracodawcy polegające na informowaniu pracownika o ewentualnych uchybieniach, a także wskazanie alternatywnych sposobów prowadzących do lepszego (zgodnego z oczekiwaniem pracodawcy) wykonywania obowiązków w przyszłości. W ten sposób zmniejszeniu powinno ulec ryzyko utraty zatrudnienia, co z perspektywy ochrony przed wypowiedzeniem jest najistotniejszym celem opiniowania pracowników ${ }^{16}$.

Modelowy schemat procedowania przy dokonywaniu oceny okresowej, która ma spełniać zakładane cele, powinien składać się z czterech etapów.

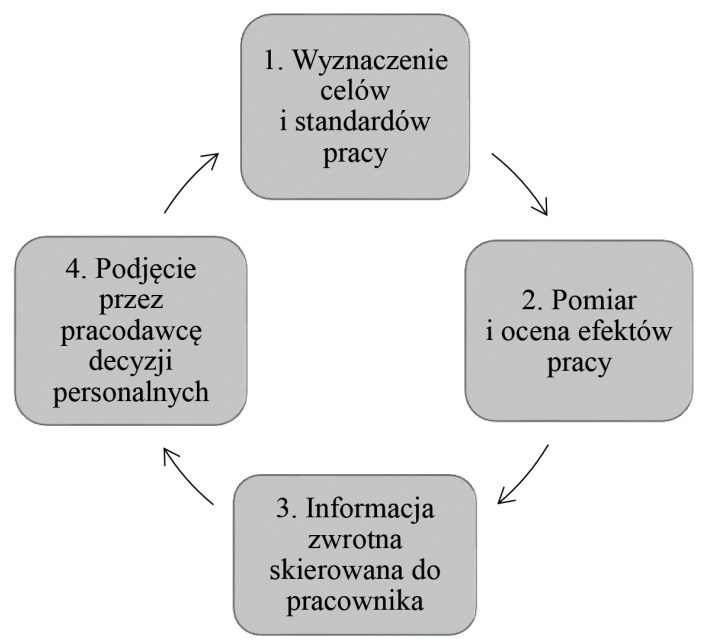

Źródło: A. Pocztowski, [w:] Zarzadzanie zasobami ludzkimi. Strategie - procesy - metody, Warszawa 2007, s. 243.

15 Tak M. Mazuryk, [w:] Ustawa o pracownikach urzędów państwowych. Komentarz, red. W. Drobny, M. Mazuryk, P. Zuzankiewicz, Warszawa 2012, LEX.

16 Zob. L. Mitrus, op. cit. 
Z perspektywy celu i funkcji oceny okresowej nie bez znaczenia jest również, kto tej oceny dokonuje. $Z$ założenia powinien to być bezpośredni przełożony. W celu uniknięcia wątpliwości, kto jest bezpośrednim przełożonym, w określonych sytuacjach ustawodawca wskazuje w sposób wyraźny na przykład osobę dokonującą oceny członków korpusu służby cywilnej zatrudnionych na stanowiskach kierowniczych. Jednakże rola bezpośredniego przełożonego może zostać sprowadzona jedynie do obowiązku sporządzenia opinii, na której powinna zostać oparta ocena okresowa (na przykład ustawa o pracownikach urzędów państwowych, pracownicy sądów i prokuratury). Natomiast oceny dokonuje w takich przypadkach inny wyznaczony podmiot lub powołana w tym celu komisja. Oznacza to, że oceniający nie jest osobą bezpośrednio współpracującą z ocenianym, a oceny dokonuje na podstawie opinii (lub wielu opinii cząstkowych) sporządzoną przez innych współpracowników, w tym przez bezpośredniego przełożonego. Należy podkreślić, że semantyka tych regulacji wskazuje, że podmiot odpowiedzialny (na przykład dyrektor sądu, prezes sądu), wystawiając ocenę okresową, jedynie bierze pod uwagę opinię bezpośredniego przełożonego i komisji kwalifikacyjnej, a nie jest nią związany ${ }^{17}$. Mając to na uwadze, istotne jest więc przygotowanie oceniającego do samej procedury oceniającej, w tym do rozmowy z pracownikiem, jeżeli taka na gruncie obowiązujących regulacji jest wymagana.

Podsumowując, można wskazać, że głównym celem ocen okresowych nie jest kontrolowanie i rozliczenie za każde, nawet najmniejsze niedociągnięcie w pracy ani ocena moralna pracowników. Ich wartość należy postrzegać w wymiarze pozytywnym. Oceny okresowe pomagają poprawiać efektywność pracy, podejmować decyzje kadrowe (awanse, przeniesienia) czy planować zatrudnienie. Są one również pomocne w ustalaniu ścieżek kariery pracowników, kształtowaniu wysokości ich wynagrodzeń ( $w$ tym zakresie system ocen okresowych powinien być spójny z polityką wynagrodzeń) czy nagradzaniu.

\section{KRYTERIA OCENY}

Efektywność ewaluacji pracowników realizowana jest przez określenie odpowiednich kryteriów oceny. Także weryfikacja realizacji celów wyznaczonych pracownikowi ma nastąpić przez ustalenie tychże (z uwzględnieniem katalogów kryteriów przewidzianych w pragmatykach lub aktach do nich wykonawczych). Niezwykle istotne jest zatem, żeby utworzona procedura (mechanizm) oceniania uwzględniała przyjęte wcześniej kryteria, zasady i cele, które stanowią układ odniesienia, niezbędny do racjonalnego jej wykorzystania ${ }^{18}$. Bez względu na liczbę

17 Zob. art. 8 ustawy o pracownikach sądów i prokuratury.

18 H. Król, A. Ludwiczyński, Zarządzanie zasobami ludzkimi - tworzenie kapitału ludzkiego, Warszawa 2006, s. 289-292. 
i rodzaj przyjętych kryteriów ocennych muszą one być znane podlegającym ocenie pracownikom przed rozpoczęciem okresu, którego ocena dotyczy. Pracownik, któremu powierzono określone stanowisko i postawiano określone wymagania, szczególnie co do jakości pracy (jej poziomu merytorycznego), będzie oceniany właśnie przez pryzmat wyznaczonych mu obowiązków i sformułowanych wymagań. W orzecznictwie wskazuje się, że nie mogą stanowić kryterium oceny pracy oczekiwania pracodawcy, o których pracownik nie wiedział, zawierając umowę o pracę, i o których pracodawca nie poinformował go w czasie trwania stosunku $\operatorname{pracy}^{19}$.

Patrząc na analizowane zagadnienie od strony gwarancji konstytucyjnych, należy wskazać art. 47 Konstytucji RP zapewniający każdemu obywatelowi ochronę prawną czci i dobrego imienia oraz art. 24, 66 ust. 1 i art. 68 Konstytucji RP zawierający gwarancję ochrony pracy. Konkretyzacją pierwszej z wymienionych kategorii wolności obywatelskich są między innymi art. 23 i art. 24 k.c. oraz art. $11^{1}$ k.p. regulujące problematykę ochrony dóbr osobistych na płaszczyźnie każdej z tych gałęzi prawa. Przepisy te traktują o odpowiedzialności pracodawcy za naruszenie dóbr osobistych pracownika, a w szczególności jego czci, godności pracowniczej i dobrego imienia. Natomiast urzeczywistnieniem konstytucyjnych gwarancji w zakresie ochrony pracy, w sferze prawa pracy, jest między innymi art. 94 pkt 9 k.p. nakładający na pracodawcę obowiązek stosowania obiektywnych i sprawiedliwych kryteriów oceny pracowników oraz wyników ich pracy. Zgodnie zaś z art. $11^{1}$ k.p. pracodawca powinien szanować godność i inne dobra osobiste pracownika ${ }^{20}$, a obowiązek ten podniesiony został przez ustawodawcę do rangi jednej z podstawowych zasad prawa pracy.

Nadanie zatem procesowi oceniania transparentności wymaga zastosowania przesłanek wynikających z art. 94 pkt 9 k.p. w odniesieniu do wszystkich kryteriów, które legły u podstaw oceny. Pracodawca, realizując swoje uprawnienie do oceniania pracowników, obowiązany jest stosować obiektywne i sprawiedliwe kryteria oceny pracowników oraz wyników ich pracy. Ponadto wynikający $\mathrm{z}$ art. 94 pkt 9 k.p. obowiązek pracodawcy koresponduje z wyrażoną $\mathrm{w}$ art. $11^{2}$ k.p. zasadą równego traktowania oraz w art. $11^{3}$ k.p. i art. $18^{3 \mathrm{a}} \mathrm{k}$.p. zasadą niedyskryminacji w stosunkach pracy. W doktrynie wskazuje się na kryteria obiektywne, które oparte są na elementach faktycznych w oderwaniu od własnych opinii, uczuć

19 Zob. wyrok Sądu Najwyższego z dnia 10 listopada 1998 roku, I PKN 428/98, LEX nr 38495.

20 Odrębną kategorią dóbr osobistych podlegających ochronie jest godność pracownicza, rozumiana jako poczucie własnej wartości oparte na opinii dobrego fachowca i sumiennego pracownika oraz na uznaniu zdolności, umiejętności i wkładu pracy pracownika przez jego przełożonych. Naruszeniem tak rozumianej godności pracowniczej są zaś zachowania pracodawcy polegające między innymi na słownej lub czynnej zniewadze, dopuszczaniu się czynów nieobyczajnych wobec pracownika, krzywdzących ocenach jego kwalifikacji, udzielaniu nieprawdziwych opinii o pracowniku, bezzasadnym wymierzaniu mu kar dyscyplinarnych, ujawnianiu bez zgody pracownika informacji objętych ochroną danych osobowych. (por. wyrok Sądu Najwyższego z dnia 21 października 2008 roku, II PK 71/08, LEX nr 1110973). 
i interesów czy uprzedzeń oceniającego, oraz na kryteria sprawiedliwe. Te ostatnie powinny być dostosowane do doświadczenia zawodowego i wykształcenia pracownika, miejsca, jakie zajmuje on w hierarchii organizacyjnej obowiązującej u pracodawcy, a także rodzaju wykonywanej pracy ${ }^{21}$. Stosowane w procesie ocennym kryteria powinny być też jawne i sprawdzalne. Tylko takie umożliwiają pomiar efektów wykonywanej pracy ${ }^{22}$. Innymi słowy, zawarty w art. 94 pkt 9 k.p. postulat stosowania obiektywnych i sprawiedliwych kryteriów oceny zmierza do wyeliminowania z procedury dokonywania ocen okresowych opinii subiektywnych i niesprawiedliwych. W świetle orzecznictwa nieobiektywna lub niesprawiedliwa ocena pracy pracownika jest zachowaniem bezprawnym. Postępowanie pracodawcy wyczerpujące przesłankę bezprawności ma miejsce, gdy dokonana przezeń ocena pracownika pozostaje wprawdzie w związku z wykonywaniem pracy danego rodzaju, jednak zawiera osądy i sformułowania, które poniżają godność zatrudnionego, albo też ocena pracownika nie pozostaje w związku ze świadczoną pracą ${ }^{23}$. Należy przyjąć, że negatywna ocena kwalifikacyjna nie będzie naruszała dóbr osobistych pracownika, o ile nie można przypisać jej cech bezprawności. W sytuacji uznania, że ocena nie została dokonana na podstawie obiektywnych i sprawiedliwych kryteriów, sąd nie zmienia oceny okresowej, a jedynie działa kasatoryjnie (uchyla ją), co obliguje pracodawcę do jej ponownego sporządzenia. Kontroli sądu podlega zatem zachowanie przez pracodawcę standardów, jakie wyznacza art. 94 pkt 9 k.p., zgodnie z którymi pracodawca jest zobowiązany stosować obiektywne i sprawiedliwe kryteria oceny pracowników oraz wyników ich pracy ${ }^{24}$.

Wskazanie przez ustawodawcę kryteriów, które obligatoryjnie brane są pod uwagę przy dokonywaniu oceny okresowej pracowników sfery publicznej, jest wyrazem sformalizowanego charakteru tej oceny. Stopień sformalizowania jest odmienny w zależności od pragmatyki. Pragmatyki bądź ustalają własne katalogi kryteriów, które mają być zastosowane w procesie oceniania, bądź zawarte są one w aktach wykonawczych do nich. Część zaś pozostawia obowiązek sformułowania katalogu kryteriów podmiotom odpowiedzialnym według ustawy za przeprowadzanie oceny okresowej. Co do zasady kryteria oceny dzielą się na kryteria obowiązkowe i kryteria dodatkowe, które oceniający może wybrać, jeżeli jest to uzasadnione ze względu na charakter obowiązków wynikających z opisu stanowiska pracy zajmowanego przez ocenianego. Jeżeli natomiast ustawodawca nie wprowadza różnicowania stosowanych kryteriów pod względem ich wagi

${ }^{21}$ Zob. D. Dörre-Kolasa, [w:] Kodeks pracy. Komentarz, red. A. Sobczyk, Warszawa 2018, s. 461.

22 Tak M. Nałęcz, [w:] Kodeks pracy. Komentarz, red. W. Muszalski, Warszawa 2017, Legalis.

23 Zob. postanowienie Sądu Najwyższego z dnia 16 marca 2000 roku, I PKN 673/99, OSNAPiUS 2001, nr 15, poz. 491.

${ }^{24}$ Zob. wyrok Sądu Najwyższego z dnia 25 sierpnia 2015 roku, II PK 223/14, LEX nr 2026882. 
(gradacji) i takiego rozróżnienia nie wprowadza również pracodawca w obowiązujących u niego autonomicznych źródłach prawa, to zasadą jest, że w procesie oceny wszystkie kryteria muszą być brane pod uwagę. Są one również względem siebie równoważne. Także do wszystkich wskazanych przez ustawodawcę kryteriów wymagane jest zastosowania przesłanek wynikających z art. 94 pkt 9 k.p. Te zaś podlegają kontroli sądowej.

Zgodnie z poglądem prezentowanym przez Sąd Najwyższy w uchwale z dnia 27 stycznia 2016 roku, III PZP 10/16²5, sąd, rozpoznając sprawę z odwołania od oceny okresowej, jest uprawniony wyłącznie do kontroli zachowania trybu dokonania oceny oraz uzasadnienia negatywnych ocen cząstkowych pod kątem prawdziwości podanych okoliczności faktycznych oraz zastosowania obiektywnych i sprawiedliwych kryteriów (art. 94 pkt 9 k.p.). Uchylenie negatywnej oceny okresowej jest dopuszczalne jedynie w przypadku naruszeń mających istotny wpływ na ostateczny wynik tej oceny okresowej, a zadaniem sądu jest w takim wypadku ocena wpływu naruszenia przepisów przez pracodawcę na wynik oceny. Kontrola sądowa obejmuje w szczególności badanie, czy pracodawca przestrzegał w danym postępowaniu obiektywnych i sprawiedliwych kryteriów oceny pracownika oraz obowiązującej procedury postępowania związanej z oceną, wyznaczonej przez ustawodawcę, szczególnie jeśli wszystkim kryteriom przypisane jest takie samo znaczenie (taka sama wartość). Oznacza to, że ocenianie pracowników podlega kontroli sądów pracy właśnie z punktu widzenia trybu obowiązującego przy dokonywaniu ocen okresowych oraz zachowania standardów wyznaczonych treścią art. 94 pkt. 9 k.p. Innymi słowy, zgodność przeprowadzonej oceny z prawem winna być oceniana zarówno w aspekcie proceduralnym, jak i materialnym. Aspekt proceduralny sprowadza się do wyjaśnienia, czy w postępowaniu oceniającym pracownika doszło do naruszeń mogących mieć wpływ na jego ostateczny wynik w postaci końcowej oceny. Jednocześnie badaniu podlega poprawność oceny w aspekcie materialnym, a zatem czy dotyczyła ona wykonywania przez pracownika wyznaczonych obowiązków i nie była dowolna. Uwarunkowania te odnoszą się do treści każdego stosunku pracy.

\section{PODSUMOWANIE}

Idealny wzorzec procedury przeprowadzania ocen okresowych pracowników, w tym również pracowników sfery publicznej (uregulowany w pragmatykach), powinien stanowić, z jednej strony, gwarancję dla kontrolowanych pracowników, że nie będą one dowolne, będą transparentne, z drugiej zaś wskazywać na (z góry) określone cele, ze względu na które pracownicy są oceniani ${ }^{26}$. W praktyce prze-

\footnotetext{
25 LEX nr 2147244.

26 Z. Góral, op. cit., s. 110.
} 
prowadzenie oceny pracownika (w tym sfery publicznej) nie powinno sprowadzać się do wykonania obowiązku (również ustawowego) dokonania przedmiotowej oceny. Niestety często zdarza się, że działanie oceniające jest prowadzone mechaniczne i polega jedynie na uzupełnieniu samego formularza oceny. Sugestie pracownika w postaci samooceny są pomijane, a rozmowa sprowadzona do monologu. W takiej postaci cel oceny okresowej nie jest realizowany, a jej funkcja motywująca pracownika do dalszego rozwoju — zaniechana.

Jak słusznie podkreśla Sąd Najwyższy, ułożenie indywidualnego mechanizmu oceny nie może być pomijane w procesie weryfikacji umiejętności pracownika, ponieważ z założenia powinien on znać oczekiwania ze strony zatrudniającego, tak by w okresie podlegającym ocenie poddać się tym kryteriom. Jest to szczególnie ważne z tej racji, że kryteria (reguły) oceny to pojęcia otwarte, niedookreślone, wartościujące, których granice między akceptowalną a ujemną postawą pracownika są płynne, zależne od cech osobistych pracownika i postrzegania go przez przełożonych w kontekście powierzanych zadań. Jednocześnie należy podkreślić, że stosowanie obiektywnych i sprawiedliwych kryteriów oceny winno polegać między innymi na tym, iż pracownik ma możliwość zapoznania się ze wszystkimi istotnymi jej kryteriami już na początku okresu podlegającego ocenie, a nie po jego zakończeniu. Tylko wówczas pracownik ma możliwość dostosowania się do owych kryteriów i podjęcia takich działań, które pozwolą na uzyskanie przez niego oceny pozytywnej.

Innymi słowy, ocena okresowa to wypadkowa wielu czynników, a sam fakt oceny negatywnej nie powinien skłaniać pracownika do wypowiedzenia posłuszeństwa pracowniczego i dalszej degradacji poziomu współpracy ${ }^{27}$. Nie można przecież nie dostrzegać, że jednym z determinantów efektywności stosowanej ewaluacji pracowników jest jej kompatybilność z potrzebami pracodawcy (organizacji, urzędu).

\section{EMPLOYEE EVALUATION — SELECTED ASPECTS}

Summary

Periodic employee evaluations are now a permanent element of the employment relationship. The evaluation mechanism existing in the public service also provides for negative effects related to the process of periodic evaluations. The aim of the article is to point out that the main purpose of periodic evaluations is, however, their positive dimension, aimed at the employee's professional development process, improving his qualifications and developing competences. On the basis of worker pragmatics, this task is difficult because the employer's behaviour is not free but should focus on the assessment of certain normative criteria using an objective measure (Article 94 point 9 of the Labour Code).

Keywords: employment relationship, periodic employee evaluation, fair and objective criteria

27 Zob. wyrok Sądu Najwyższego z dnia 16 stycznia 2019 roku, I PK 143/18, LEX nr 2607285. 


\section{BIBLIOGRAFIA}

Bocheńska A., Akademickie prawo zatrudnienia. Komentarz, red. K.W. Baran, LEX 2020.

Dörre-Kolasa D., [w:] Kodeks pracy. Komentarz, red. A. Sobczyk, Warszawa 2018.

Dubowik A., Pisarczyk Ł., Prawo urzędnicze, Warszawa 2011.

Góral Z., Funkcja ocen okresowych nauczycieli akademickich, [w:] Prawny model zatrudnienia nauczyciela akademickiego. Wybrane zagadnienia, red. A. Bocheńska, A. Musiała, Poznań 2016.

Gronowska B., Wolności, prawa i obowiazki czlowieka obywatela, [w:] Prawo konstytucyjne, red. Z. Witkowski, Toruń 2011.

Król H., Ludwiczyński A., Zarządzanie zasobami ludzkimi - tworzenie kapitału ludzkiego, Warszawa 2006.

Krzyżaniak P., Interes publiczny $w$ rozgraniczeniu funkcji oceny pracowniczej i kary porzadkowej w zakladzie pracy, MPP 2019, nr 2.

Kulig K., Teoria pracowniczej odpowiedzialności porzadkowej, Warszawa 2017.

Ludwiczyński A., [w:] Zarządzanie zasobami ludzkimi. Podręcznik, red. A. Ludwiczyński, H. Król, Warszawa 2006.

Mazuryk M., [w:] Ustawa o pracownikach urzędów państwowych. Komentarz, red. W. Drobny, M. Mazuryk, P. Zuzankiewicz, Warszawa 2012.

Mitrus L., Wypowiedzenie umowy o prace z przyczyn dotyczacych pracownika, Warszawa 2018.

Nałęcz M., [w:] Kodeks pracy. Komentarz, red. W. Muszalski, Warszawa 2017.

Pocztowski A., [w:] Zarzadzanie zasobami ludzkimi. Strategie - procesy - metody, Warszawa 2007.

Rostkowski T., Dylematy metodologiczne i praktyczne problemy badania zarzadzania zasobami ludzkimi w administracji publicznej, „Organizacja i Kierowanie” 2012, nr 1.

Sobczyk A., Państwo zakładów pracy, Warszawa 2017.

Sokolewicz W., Wojtyczek K., [w:] Konstytucja Rzeczypospolitej Polskiej. Komentarz. t. 2, red. L. Garlicki, M. Zubik, Warszawa 2016.

Szewczyk H., Stosunki pracy w stużbie cywilnej, Warszawa 2010. 